\title{
Red blood cell transfusions in very and extremely low birthweight infants under restrictive transfusion guidelines: is exogenous erythropoietin necessary?
}

A R Franz, F Pohlandt

\begin{abstract}
Objective-To examine the number and volume of red blood cell transfusions (RBCTs) in very and extremely low birthweight infants under restrictive red blood cell transfusion guidelines without erythropoietin administration, and to compare the results with those reported in similar infants receiving erythropoietin.

Methods-From April 1996 to June 1999, all RBCTs given to infants with a birth weight of less than $1500 \mathrm{~g}$ were prospectively recorded. Data on RBCT combined with erythropoietin treatment and RBCT guidelines were extracted from four prospective randomised trials of erythropoietin for anaemia of prematurity.

Results-When the restrictive RBCT guidelines were followed, the number of RBCTs and volume transfused were similar to those reported during erythropoietin administration.

Conclusions-RBCT guidelines may have a similar impact on RBCT in very low birthweight infants to the administration of erythropoietin. The effect of RBCT guidelines on RBCT frequency should be considered when evaluating the efficacy of erythropoietin administration to preterm infants.
\end{abstract}

(Arch Dis Child Fetal Neonatal Ed 2001;84:F96-F100)

Keywords: preterm; red blood cell; erythrocyte; packed cell volume; transfusion; erythropoietin

Red blood cell transfusions (RBCTs) are often given to very low birthweight infants, and $50-80 \%$ of these infants receive multiple RBCTs during their initial hospital stay. ${ }^{1-3}$ The effects of RBCT on outcome measures such as apnoea, weight gain, heart rate, and oxygen consumption have been studied in a few small randomised, mostly uncontrolled, trials and several observational studies, with controversial results (reviewed in $^{4}$ ). In the absence of uniformly accepted physiological or evidence based RBCT criteria, RBCT practices vary greatly between neonatal units, ${ }^{56}$ but, at least at first glance, these variations do not seem to result in different outcomes. ${ }^{56}$

Reducing the number of RBCTs reduces the risk of transmission of cytomegalovirus, hepatitis virus, and HIV, and may reduce costs. As frequent RBCT may be associated with retinopathy of prematurity ${ }^{78}$ and bronchopulmonary dysplasia, ${ }^{910}$ reducing the number of RBCTs may be even more important.

Erythropoietin therapy for prevention and treatment of anaemia of prematurity is still not generally recommended, ${ }^{11}$ although it has been shown to effectively stimulate erythropoiesis in vitro $^{12}{ }^{13}$ and in vivo, ${ }^{14-18}$ and was shown to be effective in reducing the need for transfusion in various age groups of preterm infants. ${ }^{14} 16$ 17 19-22 Studies have been criticised for examining relatively large preterm infants or those in a stable condition, or for giving transfusions to maintain packed cell volume at unusually high levels, thereby showing an effect of erythropoietin in infants who may not need to be transfused at all. ${ }^{1123}$ As most erythropoietin trials indeed used relatively liberal RBCT guidelines, it remains unclear whether erythropoietin administration would result in a clinically relevant reduction in the number of RBCTs to very low birthweight infants if restrictive RBCT guidelines were followed.

To gain a better understanding of whether it would be appropriate to start erythropoietin treatment in our centre, we prospectively documented all RBCTs given to our very low birthweight infants during a three year period. The aim of this study was to evaluate our RBCT practice and to compare the effect of restrictive transfusion guidelines on RBCT with the effect of erythropoietin as reported in the literature.

\section{Methods}

This study served as a surveillance of our current treatment regimen and did not require approval of our ethics committee or parental consent.

\section{PATIENTS}

All infants with a birth weight of less than 1500 g, born between April 1996 and June 1999 in our level 3 neonatal referral centre, were considered. To match the study population of the erythropoietin trials, infants with major anomalies, haemolytic disease, and twin to twin transfusion syndrome were excluded.

\section{DATA COLLECTION}

Between April 1996 and June 1999, all RBCTs to infants born at our centre with a birth weight of less than $1500 \mathrm{~g}$ were prospectively recorded. The data were compared with those recorded at the local blood bank to ensure completeness. 
Table 1 Guidelines for red blood cell transfusions in preterm infants

\begin{tabular}{|c|c|c|c|c|c|}
\hline \multirow[b]{2}{*}{ Study } & \multirow{2}{*}{\multicolumn{2}{|c|}{ Mechanically ventilated }} & \multicolumn{3}{|l|}{ Breathing spontaneously } \\
\hline & & & Raised $\mathrm{FiO}_{2}$ or signs of anaemia p & & Healthy, growing infants \\
\hline Maier et $a l^{19}$ & & $\begin{array}{l}\mathrm{Pcv}<0.40 \text { or } \\
\mathrm{Hgb}<140 \mathrm{~g} / 1 \text { or } \\
\text { blood loss }>9 \mathrm{ml} / \mathrm{kg}\end{array}$ & $\begin{array}{l}\mathrm{FiO}_{2}>0.40 \text { or }<2 \text { weeks of age } \\
\text { SoA present }\end{array}$ & $\begin{array}{l}\mathrm{Pcv}<0.40 \text { or } \\
\mathrm{Hgb}<140 \mathrm{~g} / 1 \text { or } \\
\text { blood loss }>9 \mathrm{ml} / \mathrm{kg} \\
\mathrm{Pcv}<0.32 \text { or } \\
\mathrm{Hgb}<110 \mathrm{~g} / 1\end{array}$ & $\begin{array}{l}\mathrm{Pcv}<0.27 \text { or } \\
\mathrm{Hgb}<90 \mathrm{~g} / 1\end{array}$ \\
\hline Shannon et al ${ }^{2}$ & $\begin{array}{l}\mathrm{MAP} \geqslant 6 \\
\mathrm{MAP}<6\end{array}$ & $\begin{array}{l}\mathrm{Pcv}<0.36 \\
\mathrm{Pcv}<0.31\end{array}$ & $\begin{array}{l}\mathrm{Fi}=_{2}>0.35 \\
\mathrm{FiO}_{2} 0.22-0.35 \text { or SoA present }\end{array}$ & $\begin{array}{l}P_{c v}<0.36 \\
P_{c v}<0.31\end{array}$ & $\mathrm{Pcv}<0.21$ \\
\hline Ohls et a ${ }^{20}$ & & $\mathrm{Pcv}<0.33$ & SoA present & $\mathrm{Pcv}<0.28$ & \\
\hline Maier et $a l^{25}$ & & $\mathrm{Pcv}<0.40$ & $\begin{array}{l}\mathrm{FiO}_{2}>0.40 \\
\mathrm{FiO}_{2}<0.40 \text { and } \\
<2 \text { weeks of age } \\
3-4 \text { weeks of age } \\
>4 \text { weeks of age }\end{array}$ & $\begin{array}{l}\mathrm{Pcv}<0.40 \\
\mathrm{Pcv}<0.35 \\
\mathrm{Pcv}<0.30 \\
\mathrm{Pcv}<0.25\end{array}$ & $\mathrm{Pcv}<0.25$ \\
\hline Ulm & $\begin{array}{l}\mathrm{FiO}_{2}>0.25 \\
\mathrm{FiO}_{2} \leqslant 0.25\end{array}$ & $\begin{array}{l}\mathrm{Pcv}<0.40 \\
\mathrm{Pcv}<0.30\end{array}$ & $\mathrm{FiO}_{2}>0.25$ or SoA present & $\mathrm{Pcv}<0.30$ & $\mathrm{Pcv}<0.21$ \\
\hline
\end{tabular}

$\mathrm{Pcv}$, venous centrifuged packed cell volume; $\mathrm{Hgb}$, haemoglobin concentration; $\mathrm{FiO}_{2}$, fraction of inspired oxygen; SoA, signs of anaemia; $\mathrm{MAP}$ mean airway pressure. Further indications for transfusions in Ulm at a packed cell volume of $<0.40$ were: presence of cyanotic heart disease, septic shock, major surgery, and age $<1$ week Further indications for trans
with birth weight $<1000 \mathrm{~g}$.

Birth weight and gestational age of the infant were recorded together with indication for each RBCT and volume transfused.

RBCT GUIDELINES

Restrictive RBCT guidelines were implemented (table 1). At any indication, RBCTs were given to achieve a packed cell volume of $0.45-0.50$, and were usually administered in two to three fractions over 24 hours. Leucocyte depleted packed erythrocytes from cytomegalovirus seronegative donors were used. Packed erythrocytes were reconstituted to a packed cell volume of $0.55-0.60$. Each unit was divided into four satellite bags allocated to one infant, stored for a shelf life of 14 days, and irradiated just before transfusion.

GENERAL TREATMENT GUIDELINES

Infants were fed human breast milk enriched in protein and energy (without iron supplementation) or iron supplemented preterm infant formula (12 mg iron/l). The aim was to achieve a protein intake of 3-3.5 g/ $\mathrm{kg} /$ day and an energy intake of $500-550 \mathrm{~kJ} / \mathrm{kg} /$ day. Infants received enteral iron supplementation of $2-6 \mathrm{mg} / \mathrm{kg} /$ day according to a protocol of a trial on iron supplementation. ${ }^{24}$

RBCT COMBINED WITH ERYTHROPOIETIN ADMINISTRATION

The RBCT data and RBCT guidelines were extracted from four prospective randomised trials of erythropoietin for the prevention and treatment of anaemia of prematurity. ${ }^{19} 202225$ Only randomised trials including ventilated infants were selected because more than $70 \%$ of RBCTs at our institution are given to infants on mechanical ventilation. With the exception of the study of Ohls and coworkers, ${ }^{20}$ which specifically looked at the role of erythropoietin in infants with a birth weight of less than $750 \mathrm{~g}$, trials with less than 100 patients were excluded.

COMPARISON OF RBCT FREQUENCY

For comparison with the selected erythropoietin trials, the subgroups of infants born at Ulm who would have been eligible for each erythropoietin trial according to the trial's inclusion criteria and who completed the study period of the respective erythropoietin trial at our centre were analysed. The number of RBCTs given to these subgroups and the volume transfused during the respective study period were compared with the RBCT data extracted from each erythropoietin trial.

\section{Results}

During the study period, 421 very low birthweight infants were born in our institution. Eight infants were excluded because of incomplete data collection, five had major anomalies, and eight suffered from haemolytic disease or twin-twin transfusion syndrome. This left 400 infants who were evaluated. The mean birth weight was $953 \mathrm{~g}$ (median $940 \mathrm{~g}$, range 300-1500 g), and mean gestational age was 27 weeks and 5 days (median 27 weeks, range $22-38$ weeks). Of these 400 infants, 20 died between day 1 and 287, and 172 were referred to other hospitals for continuing care between day 2 and day 69 .

A total of 569 transfusions were given to the 400 patients evaluated, with an average of 26 $\mathrm{ml} / \mathrm{kg} / \mathrm{RBCT}$. Almost half (190 infants; 47.5\%) never received a RBCT. Of these, nine had a birth weight below $750 \mathrm{~g}$, 51 a birth weight of 751-1000 g, and 130 a birth weight of 1001-1499 g. A total of 407 RBCTs (71.5\%) were given during mechanical ventilation at a mean packed cell volume of 0.34 , and 332 RBCTs (58.3\%) were given during the first two weeks of life. Nineteen RBCTs were given because the packed cell volume dropped below 0.21 in asymptomatic infants at a mean age of 40 days. Nineteen RBCTs were given not following the guidelines.

Table 1 gives the RBCT guidelines for the selected erythropoietin trials.

For comparison with the second European Multicenter Erythropoietin Trial, ${ }^{19} 180$ infants with a birth weight of 750-1499 $\mathrm{g}$ who met the inclusion criteria of the trial and who were treated for at least 42 days at our institution were analysed. Patient characteristics were 
similar, with a higher proportion of extremely low birthweight infants in our patients (table 2). The number of RBCT-free patients and the

Table 2 Red blood cell transfusion practices: comparison with the 2nd European Multicenter Trial of EPO

\begin{tabular}{lllc}
\hline & & \multicolumn{2}{l}{ EPO trial } \\
\cline { 3 - 4 } & Ulm No EPO & 750 IU EPO/week & No EPO \\
\hline Number & 180 & 120 & 121 \\
Birth weight (g) & $1100(930 ; 1260)$ & $1190(1040 ; 1370)$ & $1150(983 ; 1310)$ \\
$750-999 \mathrm{~g}$ & $62(34)$ & $61(25)$ \\
$1000-1249 \mathrm{~g}$ & $68(38)$ & $29(36)$ \\
$1250-1499 \mathrm{~g}$ & $50(28)$ & $94(39)$ \\
Gestational age (weeks) & $29(27 ; 30)$ & $29(27 ; 30)$ & $136(56)$ \\
Gestational age <30 weeks & $119(66)$ & $60(50)$ & $40(33)$ \\
Not transfused (day 3-42) & $134(74)$ & 0.87 & 1.25 \\
Mean RBCT/infant & 0.38 &
\end{tabular}

As appropriate, values are median (quartiles) or number (\%).

EPO, Erythropoietin; RBCT, red blood cell transfusion.

Table 3 Red blood cell transfusion practices: comparison with the 3rd European Multicenter Trial of EPO

\begin{tabular}{llll}
\hline & & \multicolumn{2}{l}{ EPO trial } \\
\cline { 3 - 4 } & Ulm No EPO & 750 IU EPO /week & 1500 IU EPO /week \\
\hline Number & 88 & 92 & 91 \\
Birth weight (g) & $810(710 ; 900)$ & $793(678 ; 890)$ & $800(680 ; 920)$ \\
Gestational age (weeks) & $26(25 ; 27)$ & $26(25 ; 27)$ & $27(25 ; 28)$ \\
Gestational age <28 weeks & $77(88)$ & & $139(76)$ \\
Gestational age 28-29 weeks & $11(13)$ & & $44(24)$ \\
Not transfused (after day 3) & $31(35)$ & $29(32)$ & $29(32)$ \\
Infants with 1 RBCT & $21(24)$ & $19(21)$ & $20(22)$ \\
Infants with 2 RBCT & $18(20)$ & $14(15)$ & $14(15)$ \\
Infants with 3 RBCT & $8(9)$ & $8(9)$ & $5(5)$ \\
Infants with >3 RBCT & $11(13)$ & $22(24)$ & $23(25)$ \\
Volume transfused (ml/infant) & $19.3(0 ; 33.6)$ & $12.9(0 ; 22.0)$ & $10.5(0 ; 25.0)$ \\
\hline
\end{tabular}

As appropriate, values are median (quartiles) or number (\%).

EPO, Erythropoietin; RBCT, red blood cell transfusion.

Table 4 Red blood cell transfusion practices: comparison with the American Multicenter Trial of EPO in Infants $<1251 \mathrm{~g}^{22}$

\begin{tabular}{|c|c|c|c|}
\hline & \multirow[b]{2}{*}{ Ulm No EPO } & \multicolumn{2}{|l|}{ EPO trial } \\
\hline & & $500 \mathrm{IU} E P O /$ week & No EPO \\
\hline Number & 140 & 77 & 80 \\
\hline Mean birth weight $(\mathrm{g})$ & 907 & 923 & 925 \\
\hline$\leqslant 750 \mathrm{~g}$ & $35(25)$ & $13(17)$ & $17(21)$ \\
\hline $751-1000 \mathrm{~g}$ & $54(39)$ & $39(51)$ & $31(39)$ \\
\hline $1001-1250 \mathrm{~g}$ & $51(36)$ & $25(32)$ & $32(40)$ \\
\hline Mean gestational age (weeks) & 27.0 & 26.8 & 27.1 \\
\hline Not transfused ${ }^{\star}$ & $72(51)$ & $33(43)$ & $25(31)$ \\
\hline Mean RBCT/infant ${ }^{\star}$ & 0.964 & 1.1 & 1.6 \\
\hline Mean volume transfused ${ }^{\star}$ ( $\mathrm{ml} /$ infant $)$ & 13.5 & 16.5 & 23.9 \\
\hline
\end{tabular}

Where appropriate, values are number (\%)

*During the observation period-that is, for 42 days after study entry in the Shannon trial and for days 7-64 at the Ulm centre.

EPO, Erythropoietin; RBCT, red blood cell transfusion.

Table 5 Red blood cell transfusion practices: comparison with the American Trial of Early EPO in Infants $<751 \mathrm{~g}^{20}$

\begin{tabular}{llll}
\hline & & \multicolumn{2}{l}{ EPO trial } \\
\cline { 4 - 4 } \cline { 4 - 4 } & Elm No & $\begin{array}{l}750 \text { IU EPO } \\
\text { lweek }\end{array}$ & No EPO \\
\hline Number & 66 & 15 & 13 \\
Mean birth weight (g) & 613 & 677 & 660 \\
Mean gestational age (weeks) & 25.3 & 24.3 & 24.9 \\
Mean RBCT (RBCT/infant) & 2.44 & 4.7 & 7.5 \\
Mean volume transfused (ml/kg/infant) & $71^{\star}$ & $70^{\star}$ & $112^{\star}$ \\
Mean erythrocyte volume transfused (ml/kg/infant) & $39^{\star}$ & $54^{\star}$ & $87^{\star}$ \\
\hline
\end{tabular}

*Packed erythrocytes were reconstituted to different packed cell volumes $(0.50-0.60$ at Ulm, $0.75-0.80$ at the American Centres).

EPO, Erythropoietin; RBCT, red blood cell transfusion.

\section{Key messages}

- Indications for RBCT in preterm infants are controversial

- RBCT to very low birthweight infants can be reduced to the rate reported during erythropoietin administration if restrictive transfusion guidelines are applied

- When evaluating trials of erythropoietin administration to reduce RBCT in preterm infants, the effect of the transfusion guidelines applied during these studies should be taken into account

- Trials on RBCT and erythropoietin administration should focus on long term neurodevelopmental outcome

mean number of RBCTs per patient were considerably lower at our institution (table 2).

For comparison with the third European Multicenter Erythropoietin Trial, ${ }^{25}$ all infants with a birth weight of 500-999 $\mathrm{g}$ were selected, who were treated at Ulm until discharge. Patient characteristics and the number of RBCTs given were similar in our patients and in the erythropoietin treated patients (table 3). However, if transfused, our patients received a higher total amount of packed red cells per transfusion.

According to the inclusion criteria of the American Multicenter Trial by Shannon et al, ${ }^{22}$ all infants with a birth weight below $1251 \mathrm{~g}$ and a gestational age of less than 31 weeks were selected. As patients were enrolled into this trial on different days of life, it was impossible to match the observation period exactly. For the patients treated at our institution, all RBCTs during an observation period from day 7 to day 64 are reported (which is a longer period than the 42 day study period in the trial). Again patient characteristics and results were similar in erythropoietin treated patients and patients in our centre (table 4).

For comparison with the erythropoietin trial of Ohls and coworkers, ${ }^{20}$ all patients with a birth weight of less than $751 \mathrm{~g}$ who were treated in our centre until day 21 were selected. Again our patients were less frequently transfused; however, the mean gestational age was higher in our patients (table 5). After exclusion of patients with a gestational age of more than 26 weeks to match the mean gestational age in the trial of Ohls et al, the mean number of transfusions was 2.69/infant and the mean volume transfused was $78 \mathrm{ml} / \mathrm{kg} /$ infant. Whereas patients in Ulm and in this trial received similar volumes of RBCT, packed red cells were more concentrated in the American study centres (to a packed cell volume of $0.75-0.80$ ).

\section{Discussion}

The results of this three year prospective observational study of RBCT practice indicate that a low number and low cumulative volume of RBCTs can be achieved in very low birthweight infants even without erythropoietin treatment. It has been shown previously 
that RBCT guidelines effectively reduce the number of RBCTs, ${ }^{27}$ but this is the first report to compare RBCT practice under RBCT guidelines with that during erythropoietin administration.

Apart from variations in RBCT guidelines, differences in antenatal corticosteroid treatment, initial morbidity, ${ }^{28}$ iron and protein supplementation, ${ }^{18} 24$ 29-32 and, most importantly, phlebotomy losses s $^{33-36}$ probably occurred and influenced the need for RBCT. The observation that infants received fewer RBCTs at our institution than at the American centres $^{20} 22$ despite similar RBCT guidelines suggests such differences in general care.

Most RBCT guidelines are based on thresholds of haemoglobin level or packed cell volume. However, haemoglobin level and packed cell volume correlate poorly with red cell mass, ${ }^{37}{ }^{38}$ and may not be a good predictor of oxygen delivery ${ }^{39}$ and benefit from RBCT. ${ }^{3840} 41$ Improvement of oxygen carrying capacity after RBCT in asymptomatic infants with haemoglobin levels of $110-130 \mathrm{~g} / 1,{ }^{39}$ and in oxygen dependent non-ventilated preterm infants with haemoglobin levels of $65-88 \mathrm{~g} / 1,{ }^{42}$ did not result in a change in oxygen consumption, indicating that oxygen delivery was adequate before transfusion. Furthermore, adequate adaptation of cardiac output effectively attenuated the effects of variations in packed cell volume on systemic oxygen carrying capacity in preterm infants. ${ }^{43}$ We therefore hypothesise that, as long as an infant is growing and asymptomatic at a low packed cell volume, his/her oxygen delivery is adequately maintained.

Reducing the number of RBCTs may result in a reduction in costs, risk of viral infection, and retinopathy of prematurity ${ }^{78}$ and other diseases thought to be caused by free radicals, ${ }^{9} 10$ but there is no evidence that achieving this reduction by accepting low packed cell volumes in asymptomatic infants is safe and benefits the patient. The safety and efficacy of this approach can only be evaluated in a large study with long term neurodevelopmental follow up. All current recommendations on RBCT, ${ }^{1445}$ however, are not based on data on long term outcome.

As a crude measure of overall outcome, mortality before discharge (including mortality at the affiliated hospitals) was $6 \%$ in the 400 infants evaluated in this study and $7.6 \%$ in all 421 patients born at our institution during this three year period, and was not increased compared with recently published outcome data (16\% mortality in 4593 infants with a birth weight of less than $1500 \mathrm{~g}) .^{46}$

We conclude that under restrictive transfusion guidelines with adequate protein and iron supplementation, RBCT can be reduced to the rate reported erythropoietin treatment. It is currently unclear which approach benefits preterm infants most, and both approaches may be regarded as experimental. Randomised controlled trials focusing on long term neurodevelopmental outcome are necessary to provide better evidence of efficacy and safety of RBCT practices. As long as the indications for RBCT are controversial, results of erythropoietin trials will remain inconclusive.

1 Bifano EM, Curran TR. Minimizing donor blood exposure in the neonatal intensive care unit. Current trends and in the neonatal intensive care unit. Current t

2 Widness JA, Seward VJ, Kromer IJ, et al. Changing patterns of red blood cell transfusion in very low birth weight infants. F Pediatr 1996;129:680-7.

3 Asch J, Wedgwood JF. Optimizing the approach to anemia in the preterm infant: is there a role for erythropoietin therapy? $\mathcal{F}$ Perinatol 1997;17:276-82.

4 Hume H. Red blood cell transfusions for preterm infants: the role of evidence-based medicine. Semin Perinatol 1997;21:8-19.

5 Bednarek FJ, Weisberger S, Richardson DK, et al. Variations in blood transfusions among newborn intensive care units. SNAP II Study Group. I Pediatr 1998;133:601-7.

6 Ringer SA, Richardson DK, Sacher RA, et al. Variations in transfusion practice in neonatal intensive care. Pediatrics 1998;101:194-200.

7 Hesse L, Eberl W, Schlaud M, et al. Blood transfusion. Iron load and retinopathy of prematurity. Eur $\mathcal{F}$ Pediatr 1997; 156:465-70.

8 Inder TE, Clemett RS, Austin NC, et al. High iron status in very low birth weight infants is associated with an increased risk of retinopathy of prematurity. 7 Pediatr 1997;131:541-4

9 Silvers KM, Gibson AT, Russell JM, et al. Antioxidant activity, packed cell transfusions, and outcome in premature infants. Arch Dis Child 1998;78:F214-19.

10 Cooke RW, Drury JA, Yoxall CW, et al. Blood transfusion and chronic lung disease in preterm infants. Eur $\mathcal{F}$ Pediatr 1997;156:47-50.

11 Strauss RG. Recombinant erythropoietin for the anemia of prematurity: still a promise, not a panacea. 7 Pediatr 1997;131:653-5.

12 Rhondeau SM, Christensen RD, Ross MP, et al. Responsiveness to recombinant human erythropoietin of marrow erythroid progenitors from infants with the anemia of prematurity. F Pediatr 1988;112:935-40.

13 Shannon KM, Naylor GS, Torkildson JC, et al. Circulating erythroid progenitors in the anemia of prematurity. $N$ Engl erythroid progenitors in

14 Ohls RK, Christensen RD. Recombinant erythropoietin compared with erythrocyte transfusion in the treatment of anemia of prematurity. F Pediatr 1991;119:781-8.

15 Shannon KM, Mentzer WC, Abels RI, et al. Enhancement of erythropoiesis by recombinant human erythropoietin in ow birth weight infants: a pilot study. $\mathcal{f}$ Pediatr 1992;120:586-92.

16 Carnielli V, Montini G, Da Riol R, et al. Effect of high doses of human recombinant erythropoietin on the need for blood transfusions in preterm infants. $f$ Pediatr 1992;121:98-102.

17 Soubasi V, Kremenopoulos G, Diamandi E, et al. In which neonates does early recombinant human erythropoietin treatment prevent anemia of prematurity? Results of a randomized, controlled study. Pediatr Res 1993;34:675-9.

18 Bechensteen $\mathrm{AG}$, Hågå $\mathrm{P}$, Halvorsen $\mathrm{S}$, et al. Erythropoietin, protein, and iron supplementation and the prevention of protein, and iron supplementation and the prevention

19 Maier RF, Obladen M, Scigalla P, et al. The effect of epoetin beta (recombinant human erythropoietin) on the need for transfusion in very-low-birth-weight infants. European Multicentre Erythropoietin Study Group. $N$ Engl f Med 1994;330:1173-8.

20 Ohls RK, Harcum J, Schibler KR, et al. The effect of erythropoietin on the transfusion requirements of preterm infants weighing 750 grams or less: a randomized, doubleblind, placebo-controlled study. F Pediatr 1997;131:661-5.

21 Meyer MP, Meyer JH, Commerford A, et al. Recombinant human erythropoietin in the treatment of the anemia of prematurity: results of a double-blind, placebo-controlled study. Pediatrics 1994;93:918-23.

22 Shannon KM, Keith JFr, Mentzer WC, et al. Recombinant human erythropoietin stimulates erythropoiesis and reduces erythrocyte transfusions in very low birth weight preterm infants. Pediatrics 1995;95:1-8.

23 Strauss RG. Red blood cell transfusion practices in the neonate. Clin Perinatol 1995;22:641-55.

24 Franz A, Mihatsch W, Sander S, et al. Prospective randomized trial of early versus late enteral iron supplementation in infants with a birth weight of less than 1301 grams. Pediatrics 2000;106:700-6.

25 Maier RF, Obladen M, Kattner E, et al. High-versus low-dose erythropoietin in extremely low birth weight infants. The European Multicenter rhEPO Study Group. $\mathcal{F}$ Pediatr 1998;132:866-70.

26 Maier RF, Günther A, Vogel M, et al. Umbilical venous erythropoietin and umbilical arterial $\mathrm{pH}$ in relation to morphologic placental abnormalities. Obstet Gynecol 1994;84:81-7.

27 Alagappan A, Shattuck KE, Malloy MH. Impact of transfusion guidelines on neonatal transfusions. I Perinatol 1998; 18:92-7.

28 Kling PJ, Sullivan TM, Leftwich ME, et al. Score for neonatal acute physiology and phlebotomy blood loss predict erythrocyte transfusions in premature infants. Arch Pediatr erythrocyte transfusions in prem

29 Lundström U, Siimes MA, Dallman PR. At what age does iron supplementation become necessary in low-birthweight infants? F Pediatr 1977;91:878-83. 
30 Rönnholm KA, Siimes MA. Haemoglobin concentration depends on protein intake in small preterm infants fed
human milk. Arch Dis Child 1985;60:99-104.

31 Bechensteen AG, Halvorsen S. Parenteral iron increases serum erythropoietin concentration during the early anaemia of 10-20-day-old mice. Br f Haematol 1996;94:529 32.

32 Brown MS, Shapiro H. Effect of protein intake on erythropoiesis during erythropoietin treatment of anemia of prematurity. I Pediatr 1996;128:512-17.

33 Blanchette VS, Zipursky A. Assessment of anemia in newborn infants. Clin Perinatol 1984;11:489-510.

34 Shannon K. Recombinant human erythropoietin in neonatal anemia. Clin Perinatol 1995;22:627-40.

35 Maier RF, Obladen M, Messinger D, et al. Factors related to transfusion in very low birthweight infants treated with erythropoietin. Arch Dis Child 1996;74:F182-6.

36 Maier RF, Metze B, Obladen M. Low degree of regionalization and high transfusion rates in very low birthweight infants: a survey in Germany. F Perinat Med 1998;26:43-8.

37 Jones JG, Holland BM, Hudson IR, et al. Total circulating red cells versus haematocrit as the primary descriptor of oxygen transport by the blood. $\mathrm{Br} \quad \mathcal{f}$ Haematol 1990;76:288-94

38 Hudson I, Cooke A, Holland B, et al. Red cell volume and cardiac output in anaemic preterm infants. Arch Dis Child 1990;65:672-5.
39 Wardle SP, Yoxall CW, Crawley E, et al. Peripheral oxygenation and anemia in preterm babies. Pediatr Res tion and anem

40 Alverson DC, Isken VH, Cohen RS. Effect of booster blood transfusions on oxygen utilization in infants with bronchopulmonary dysplasia. F Pediatr 1988;113:722-6.

41 Blank JP, Sheagren TG, Vajaria J, et al. The role of RBC transfusion in the premature infant. American fournal of Diseases in Children 1984;138:831-3.

42 Bard H, Fouron JC, Chessex P, et al. Myocardial, erythropoietic, and metabolic adaptations to anemia of prematurity in infants with bronchopulmonary dysplasia. $\mathcal{F}$ Pediatr 1998;132:630-4.

43 Pladys P, Beuchee A, Wodey E, et al. Haematocrit and red blood cell transport in preterm infants: an observational study. Arch Dis Child 2000;82:F150-5.

44 Linderkamp O, Zilow EP, Zilow G. [The critical hemoglobin value in newborn infants, infants and children]. globin value in newborn infants, infants and children

45 Blanchette VS, Hume HA, Levy GJ, et al. Guidelines for auditing pediatric blood transfusion practices. American auditing pediatric blood transfusion practices.

46 Stevenson DK, Wright LL, Lemons JA, et al. Very low birth weight outcomes of the National Institute of Child Health and Human Development Neonatal Research Network, January 1993 through December 1994. Am f Obstet Gynecol 1998;179:1632-9. 